\title{
An evolutionary explanation of female-biased sexual size dimorphism in North Sea plaice, Pleuronectes platessa L.
}

\author{
Fabian Mollet ${ }^{1}$, Katja Enberg ${ }^{2}$, David Boukal ${ }^{3}$, Adriaan Rijnsdorp ${ }^{4}$, and Ulf Dieckmann ${ }^{1}$ \\ ${ }^{1}$ International Institute for Applied Systems Analysis \\ ${ }^{2} \mathrm{IMR}$ \\ ${ }^{3}$ Havforskningsinstituttet \\ ${ }^{4}$ Wageningen Universiteit en Researchcentrum IMARES
}

February 23, 2021

\begin{abstract}
Sexual size dimorphism (SSD) is caused by differences in selection pressures and life-history tradeoffs faced by males and females. Proximate causes of SSD may involve sex-specific mortality, energy acqui-sition, and energy expenditure for maintenance, reproductive tissues, and reproductive behavior. Using a quantitative, individual-based, eco-genetic model parameterized for North Sea plaice, we explore the importance of these mechanisms for female-biased SSD, under which males are smaller and reach sexual maturity earlier than females (common among fish, but also arising in arthropods and mammals). We consider two mechanisms potentially serving as ultimate causes: (1) male investments into male repro-ductive behavior might detract energy resources that would otherwise be available for somatic growth, and (2) diminishing returns on male reproductive investments might lead to reduced energy acquisition. In general, both of these can bring about smaller male body sizes. We report the following findings. First, higher investments into male reproductive behavior alone cannot explain the North Sea plaice SSD. This is because such higher reproductive investments require increased energy acquisition, which would cause a delay in maturation, leading to male-biased SSD contrary to observations. When account-ing for the observed differential (lower) male mortality, maturation is postponed even further, leading to even larger males. Second, diminishing returns on male reproductive investments alone can qualitative-ly account for the North Sea plaice SSD, even though the quantitative match is imperfect. Third, both mechanisms can be reconciled with, and thus provide a mechanistic basis for, the previously advanced Ghiselin-Reiss hypothesis, according to which smaller males will evolve if their reproductive success is dominated by scramble competition for fertilizing females, as males would consequently invest more into reproduction than growth, potentially implying lower survival rates relaxing male-male competition. Fourth, a good quantitative fit is achieved by combining both mechanisms while accounting for costs males incur during spawning.
\end{abstract}

\section{Hosted file}

Mollet_SexualSizeDimorphism_2019_CLEAN.docx available at https://authorea.com/users/397526/ articles/510375-an-evolutionary-explanation-of-female-biased-sexual-size-dimorphism-innorth-sea-plaice-pleuronectes-platessa-l 


\section{Female base model}

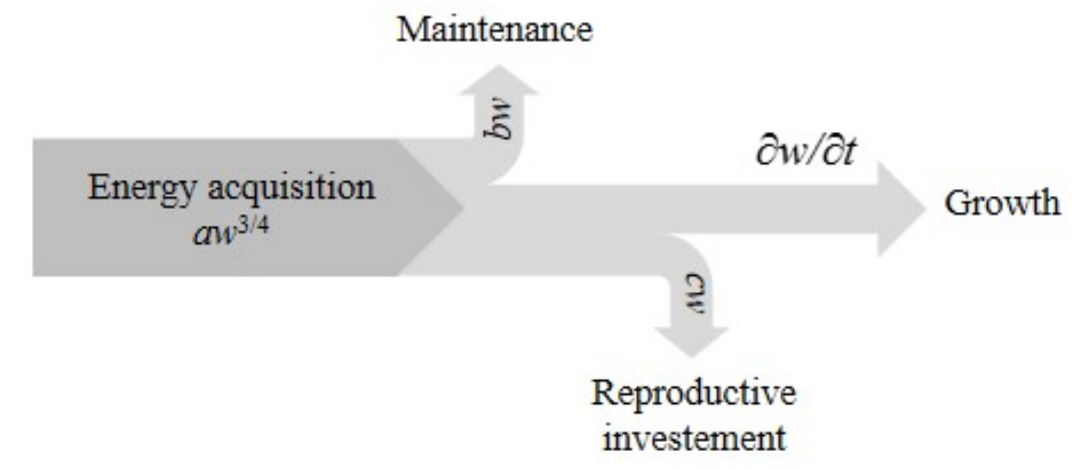

\section{Male model}

H1: Higher reproductive investment

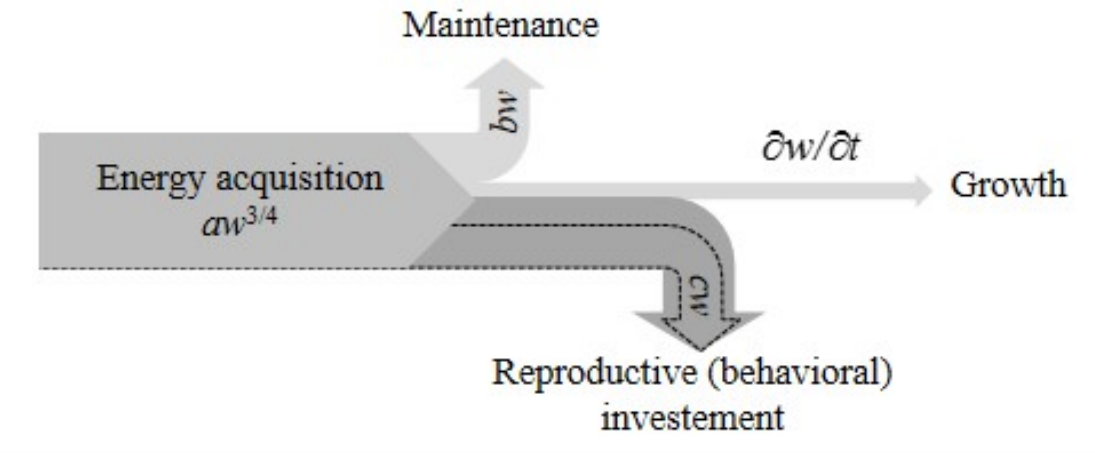

Male model

$\mathrm{H}$ 2: Lower energy acquisition

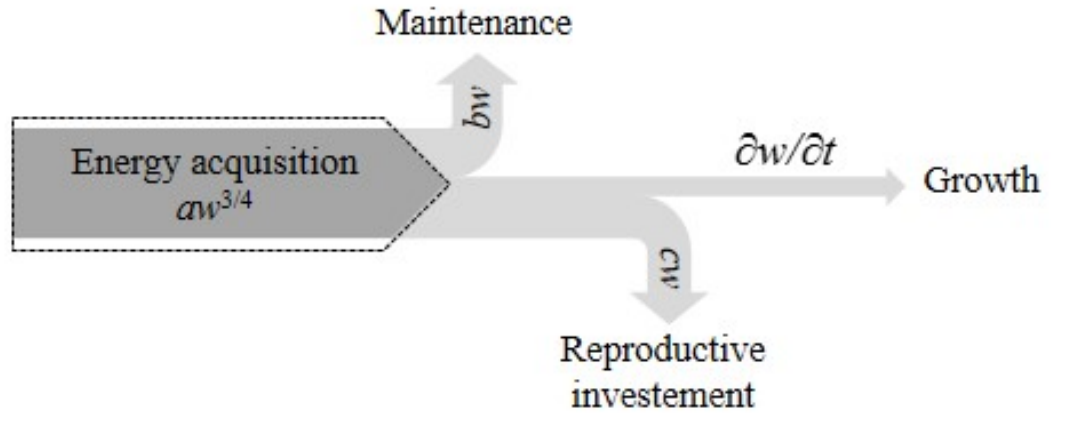




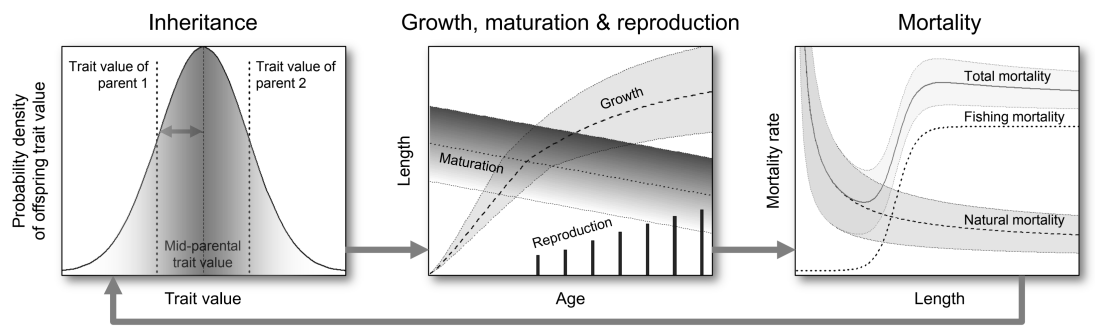

\section{Hosted file}

Fig. 3 CMK.emf available at https://authorea.com/users/397526/articles/510375-anevolutionary-explanation-of-female-biased-sexual-size-dimorphism-in-north-sea-plaicepleuronectes-platessa-1

\section{Hosted file}

Fig. 4 CMK.emf available at https://authorea.com/users/397526/articles/510375-anevolutionary-explanation-of-female-biased-sexual-size-dimorphism-in-north-sea-plaicepleuronectes-platessa-1

\section{Hosted file}

Fig. 5.emf available at https://authorea.com/users/397526/articles/510375-an-evolutionaryexplanation-of-female-biased-sexual-size-dimorphism-in-north-sea-plaice-pleuronectesplatessa-1

\section{Hosted file}

Fig. 6.emf available at https://authorea.com/users/397526/articles/510375-an-evolutionaryexplanation-of-female-biased-sexual-size-dimorphism-in-north-sea-plaice-pleuronectesplatessa-1

\section{Hosted file}

Fig. A1.emf available at https://authorea.com/users/397526/articles/510375-an-evolutionaryexplanation-of-female-biased-sexual-size-dimorphism-in-north-sea-plaice-pleuronectesplatessa-1

\section{Hosted file}

Fig. A2.emf available at https://authorea.com/users/397526/articles/510375-an-evolutionaryexplanation-of-female-biased-sexual-size-dimorphism-in-north-sea-plaice-pleuronectesplatessa-1 